
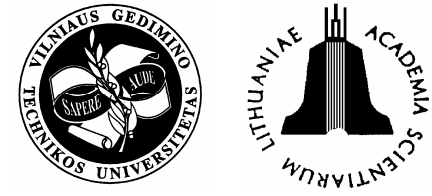

ISSN 1392-3730 print / ISSN 1822-3605 online

JOURNAL OF CIVIL ENGINEERING AND MANAGEMENT

http:/www.jcem.vgtu.lt

2007, Vol XIII, No 1, 71-76

\title{
INTERFACE CONDITION INFLUENCE ON PREDICTION OF FLEXIBLE PAVEMENT LIFE
}

\author{
Hassan Ziari ${ }^{1}$, Mohammad Mahdi Khabiri ${ }^{2,3}$ \\ ${ }^{1}$ College of Civil Engineering, Iran University of Science and Technology, Narmak, Tehran, Iran \\ E-mail:H.Ziari@iust.ac.ir \\ ${ }^{2}$ College of Civil Engineering, Iran University of Science and Technology, Narmak, Tehran, Iran \\ ${ }^{3}$ Institute of Civil Engineering, ValiAsr University, Tehran,Iran.E-mail:Khabiri@iust.ac.ir \\ Received 18 Apr 2005; accepted 02 Dec 2005
}

\begin{abstract}
The effects of interface condition on the life of flexible pavements have been determined. The methodology consists of implementing a previously derived interface constitutive model into the Kenlayer programme to compute the stresses and strains in typical flexible road structures. The shell transfer functions for fatigue cracking and terminal serviceability were used to estimate the pavement life. The behaviour of in-service pavements indicates that the condition of the bonding between pavement layers plays an important role in the road structures performance. Premature failure of road sections due to layer separation, leading to redistribution of stresses and strains in the pavement structure, is often encountered, especially in areas where the vehicles are more likely to apply horizontal forces. In computing the critical stresses and strains, most of the mechanistic design procedures of flexible pavement structures consider that pavement layers are completely bonded or completely unbounded.
\end{abstract}

Keywords: interface condition, linear elastic model, tack coat, flexible pavement, Kenlayer programme, shell transfer functions, fatigue, rutting.

\section{Introduction}

This paper presents a study on the behaviour of interface condition for asphalt pavement structures. The statement presents the mechanical and practical properties of tack coat and seal coat materials with a special regard to the determination of its resilient modulus and the permanent deformation, and by a proper material characterisation of the unbound bases. To deal with the non-linear behaviour, the mechanical attributes may be examined by a linear elastic model computer programme. To make the result user friendly, it is more advisable to go for a clever use of commonly accepted linear elastic approaches. The objective of the study is to investigate how the inaccuracies of linear elastic modelling of interface condition can be circumvented as best as possible.

Tack coat and seal coat materials can be applied in almost any road pavement structure. Therefore it is very important to know something about its behaviour. The main function of this material is to reduce the vertical compressive stress induced by traffic, in the sub-base and the subgrade, to a level at which no unacceptable deformation will occur in any layers. This study focuses on the strain dependency on the interface condition, being the most interesting and important part of the structure. It presents the mechanical of tack coat and seal coat materials with a special emphasis on determining its resilient modulus and permanent bend, which is achieved by a proper material characterisation of the interface condition.
A three-layer model was developed to investigate the mechanical and material properties of the flexible pavement. This model is provided by the computer program of the American Software Kenlayer. For modelling the non-linear behaviour granular base, asphalt layer and interface condition, Kenlayer provided excellent opportunities, not in use of the Iranian pavement designing procedure for the moment.

\section{Literature review}

All mechanistic design methods for flexible pavement structure are based on algorithms for calculating stresses, strains, and displacements in the layered structure. To ease the modelling of the structure and the computation process, most methods assume that the layers are fully bonded to each other. A few models allow the modelling of the interface bonding coefficient between 0 (no bonding) and 1 (full bonding). Even then, selection of the bonding coefficient is difficult because there is no standard test procedure to determine it. Thus, proper modelling of the interface bonding condition represents an important issue in understanding the real behaviour of road structures.

The typical distress caused by the inadequate bond between an asphalt wearing course (or asphalt overlay) and the next layer slippage cracking. This occurs most often in areas where braking or turning wheels cause the pavement surface to slide or deform (for example, inter- 
section, sharp curves), but can occur under a simple rolling wheel load. Shahin describes the slippage cracks as crescent or half-moon shaped cracks with two ends pointed away from the direction of traffic [1]. A typical example was observed at the first full-scale accelerated pavement test in Louisiana [2]. The repair option is a function of the level of severity, indicated by the crack width and density, and consists of the partial or full-depth patch of the cracked area.

Spreading an asphaltic tack coat over an under lay before placing an asphalt surface course is the technique commonly used for ensuring the bond between layers. The different experience of state highway agencies in terms of the performance of tack coats as an interface bonding material is reflected by the construction specifications for the material and quantity requirements for the tack coat, which are not uniform. Satisfactory performance has been observed on pavement structures where the tack coat has not been used and some states do not even require a tack coat to be placed before laying of the asphalt surface course or the asphalt overlay.

An example is provided that describes a flexible pavement rehabilitation project with an asphalt overlay on Interstate 40 in Tennessee [3]. The project consisted of miling $50 \mathrm{~mm}$ of existing roadway and filling the milled surface with a polymer-modified base mix followed by a surface course. The particularity of the project was that of the hot-mix overlay melted the asphalt contained in the small loose millings left in the grooved, milled pavement. The melted asphalt led to a strong bond between the placed mixture and the underlying pavement. The project not only illustrated a case in which the tack coat can be eliminated but also the need for a testing procedure for the interface.

Redistribution of stresses and strains in the pavement structure due to inadequate interface condition has been considered as a cause of premature failure for road structures for a long time. In a 1962 article, Livneh and Shklarsky wrote: "When the coefficient of friction between the asphalt carpet and the rigid base is small, this case may be more critical than of a flexible base" [1]. They considered, as a distinct design case, the situation when the friction between the base and surface layers is low. In this case, the stiff base is not included in the failure mechanism. Here the critical point is at the bottom of the surface layer; failure does not initiate in the rigid base.

To study the consequences of separation between an asphalt overlay and the existing pavement surface, Shahin et al used the BISAR model [4], based on the layered elastic theory, and the fatigue laws for asphalt concrete to compute the life of an airfield pavement. The study revealed that, for the full-bond case, the maximum tensile strain remained at the bottom of the original asphalt layer and the overlay was in compression. The tensile strain at the bottom of the overlay was larger than that at the bottom of the existing asphalt layer for the full-slip case. The strain field was almost the same for the cases of partial slip and full slip. The vertical subgrade strain also increased when the bonding was lost.
Even though the behaviour of in-service road structures indicates that the interface condition affects pavement performance, very few studies have focused on developing testing methodologies and formulating constitutive models for interface between pavement layers. A recent study by Romanoschi includes a summary of research on this topic and a new proposed interface constitutive model for the asphalt concrete layer interface as well as for the interface between the asphalt surface layer and the granular or soil - cement base layer [1].

The constitutive model for the asphalt-to-asphalt interface was derived from laboratory direct shear tests at 4 levels of normal load and at 3 temperatures. The direct shear tests at several normal pressures were selected because in this testing configuration the normal and shear stresses are decoupled and therefore the models are easier to build. Two interface types, with and without a tack coat, were sheared to failure under a guillotine type shearing test [5].

It was also found that the asphalt concrete layer interface may fail in fatigue; the increase of the permanent shear displacement with the number of load repetitions in linear. As expected, the rate of increase is higher for higher stresses. In structural modelling, it is reasonable to consider that the failure is at the interface. The reduced shearing resistance is due to the softening of soil-cement at the upper part of the base layer. This interface can be considered fully bonded up to the point when failure occurs because of the crushing of the soil-cement material. After failure, a simple friction model, described by the friction coefficient, is representative for the mechanical behaviour of the interface [5].

The limestone aggregates adhere very well to the asphalt concrete surface layer, and the shear resistance is due to aggregate interlock. In structural modelling it can be considered that the asphalt surface layer and the limestone base are fully bonded [5].

According to ASTM-D8-02 standard terminology relating to materials for road and pavements, a prime coat is "an application of a low-viscosity bituminous material to an absorptive surface, designed to penetrate, bond, and stabilise the existing surface and to promote adhesion between it and the construction course that follows"

1) The Asphalt Institute describes a prime coat as "a spray application of a medium curing cutback asphalt or emulsified asphalt applied to an untreated base course".

2) The U.S. Army Corps of Engineers (USACE), in their guide specifications for military construction, and

3) Defines a prime coat as "an application of a low viscosity liquid asphalt material on a non-bituminous base course before placement of a hot-mix asphalt (HMA) pavement" [6].

ASTM-D8 states that "the purpose of a prime coat is to penetrate, bond and stabilise the existing layer and to promote adhesion between the existing surface and the new surface". The USACE describes the purpose of a prime coat as "to penetrate and reduce the voids in the surface of an unbound base course and to bind the parti- 
cles together to form a tight, tough surface on which bituminous concrete can be placed" [7]. According to the Unified Facilities Criteria (UFC) [8], developed by the USACE, "the main purposes of a prime coat are:

1) To prevent lateral movement of the unbound base during pavement construction,

2) To waterproof during pavement construction, and

3) To form a tight, tough base to which an asphalt pavement will adhere".

There was no mention made in the handbooks reviewed supporting the notion that prime coat increases the load bearing capacity of a pavement. Prime coats are not considered structural applications. OCAPE [9] states that any time an unbound layer of material is stabilised there is a benefit; however, it would be an overstatement to claim substantial structural benefit.

Numerous references were found stating that one of the purposes of a prime was to promote bond between the granular bases and to prevent slippage [10-12]. The USACE reports that

1) An excessive amount of prime coat causes lateral movement of the asphalt concrete during rolling operations.

2) Excessive prime remaining on the surface can be absorbed into overlying asphalt layers contributing to pavement slippage or rutting.

OCAPE reported that some paving personnel believe that prime coats limit the amount of mix sliding during compaction of HMA over aggregate base but that mix crawl was more related to mix formulation and that prime alone would not eliminate the phenomenon [10].

Mantilla and Button performed direct shear tests on primed samples of aggregate base. Application rates were reported as $1,1 \mathrm{~L} / \mathrm{m}^{2}$ and a chip seal was placed between the primed base and HMA layer [11]. The prime was allowed to cure for $24 \mathrm{~h}$ at $40^{\circ} \mathrm{C}$ prior to placement of the seal coat. The seal coat was cured for 24 hours at ambient temperatures prior to placing the HMA layer. The results are reproduced in graphical form in Fig 1. The authors reported that MC-30 cutback and AEP samples performed better than unprimed samples and that PEP and low volatile organic compound (LVOC-1) prime performed similarly to the unprimed samples.

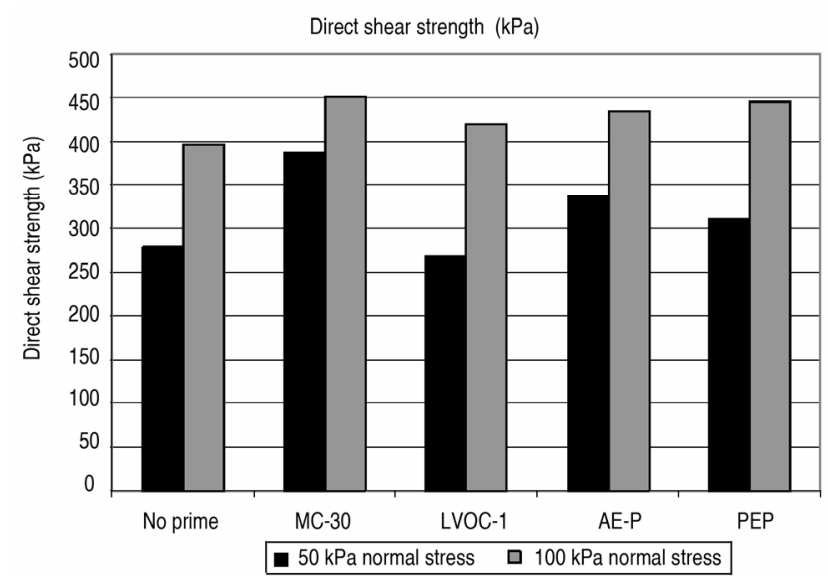

Fig 1. Direct shear strength for various prime coat materials [11]
Several papers were found in the literature search where researchers evaluated the influence of tack coat on interface shear strength of HMA layers. The results from these studies provide conflicting conclusions as to the effect of tack coat on interface shear strength. The majority of the testing reported was performed using either custom fabricated devices or devices adapted from other test procedures. The effect of the ruggedness or repeatability of many of these custom fabricated devices is unknown. The variability in test methods and testing conditions makes evaluating the influence of tack on interface shear strength problematic. Several factors were reported in the literature as having an influence on measured interface shear strength. Magnitude of the normal force [12], rate of shear and test temperature were all shown to have an effect on interface shear strength.

\section{Modelling interfaces using linear elastic model in this study}

Because of the complexity of layered structures, material models, and loading condition, no exact solution has been developed for calculating conditions, an exact solution has been developed for calculating stresses, strains, and displacements in pavement structures. Of the approximate methods that allow stress-strain computations for these complex conditions, the Kenlayer is becoming the most popular, because it can address many aspects that are important for modelling road structure: the non-linear behaviour of pavement materials, discontinuities (interface), and dynamic loading and temperature effects.

In the past decade, ABQUS [13] has gained popularity for solving stress, strain, and displacement problems in layered pavements involving non-linear subgrades and foundation layers and dynamic loading. The interface between layers can be efficiently modelled by the Kenlayer contact interaction feature. The contraction feature is commonly used to model friction between the surfaces of two rigid or elastic bodies that move against each other.

Most mechanistic structural design methods for flexible pavements are based on response models, assuming that loads are acting at a pavement surface in the vertical direction only. The loading simulated the action of a circular distributed static load, with a radius of $0,15 \mathrm{~m}$, but the tire imprint was approximated with a surface composed of squares. All materials were considered as being linear elastic to reduce the number of interactions to a convergent solution. The geometric model and materials property inputs used in the analyses are shown in Table 1.

Two interface conditions were used to model the asphalt concrete layer interface, with the surface interaction option:

- Unbonded condition,

- Full bond condition.

Two surface interaction options were used for modelling asphalt surface-aggregate base interfaces: the full bond condition and the simple friction condition. The asphalt surface was considered fully bonded to the crushed stone base layer and was modelled with the tied option. 
Table 1. Geometric and material property of pavement structure (this study)

\begin{tabular}{c|c|c|c|c}
\hline Layer & $\begin{array}{c}\text { Elasticity } \\
\text { modulus } \\
(\mathrm{Mpa})\end{array}$ & $\begin{array}{c}\text { Thickness } \\
(\mathrm{cm})\end{array}$ & $\begin{array}{c}\text { Poison's } \\
\text { ratio }\end{array}$ & $\begin{array}{c}\text { Material } \\
\text { type }\end{array}$ \\
\hline 1 & 2000 & 5 & 0.35 & Asphalt \\
\hline 2 & 1200 & 10 & 0.35 & Asphalt \\
\hline 3 & 350 & 20 & 0.40 & Base \\
\hline 4 & 250 & - & 0.35 & Soil \\
\hline
\end{tabular}

To validate our pavement model, we compared our computed results against the actual strain data reported in the literature by carrying out an extensive simulation with varying values of interface condition. Our interface condition model along with a parametric analysis matrix will help pavement engineers model various bonded interface designs. In the future, this research will lead to a breakthrough in modelling both short- and long-term performance of a interface condition on the existing pavement under various construction and deterioration conditions.

\section{Estimation of pavement life}

Kenlayer is an American computer program, so it is possible to give the units in inch and Psi or $\mathrm{m}, \mathrm{kPa}$ and $\mathrm{kN}$. SI-units were used in this study. Kenlayer can be applied to layered systems under single, dual, dualtandem, or dual-tridem wheels with each layer behaving differently, either linear elastic, non-linear elastic, or viscoelastic. Maximum 19 layers and 24 load groups are allowed in this program.

To study the influence of the interface condition on the pavement life, the stresses and strains in the pavement structure were computed for each case in Table 2 by using the finite element method. With the strain values, the shell transfer functions were used to compute pavement life [14]. The equations used in the shell method were selected only because of their simple form (subgrade strain model to a decrease in serviceability of 2,5$)$ :

$$
N_{r}=\left(0,028 / \varepsilon_{v}\right)^{4},
$$

where $N_{r}$ is the number of equivalent standard axles to final pavement serviceability index of 2,5 and $\varepsilon_{v}$ is the vertical compressive at the top of the subgrade surface.

Table 2. Interface condition in this research

\begin{tabular}{c|c|c|c|c}
\hline Case & $\begin{array}{c}\text { Wearing- } \\
\text { binder } \\
\text { interface }\end{array}$ & $\begin{array}{c}\text { Kenlayer } \\
\text { interface } \\
\text { number }\end{array}$ & $\begin{array}{c}\text { Binder-base } \\
\text { interface }\end{array}$ & $\begin{array}{c}\text { Kenlayer } \\
\text { interface } \\
\text { number }\end{array}$ \\
\hline $\boldsymbol{A}$ & Tied & 1 & Tied & 1 \\
\hline $\boldsymbol{B}$ & Tied & 1 & No & 0 \\
\hline $\boldsymbol{C}$ & No & 0 & Tied & 1 \\
\hline $\boldsymbol{D}$ & No & 0 & No & 0 \\
\hline
\end{tabular}

Fatigue cracking model (derived with laboratory specimens subjected to displacement-controlled fourpoint bending fatigue tests):

$$
N_{c}=0,0685\left(1 / \varepsilon_{t}\right)^{5,671}\left(E_{1}\right)^{-2,363},
$$

where $N_{c}$ - number of fload repetition to the failure by fatigue cracking, $\varepsilon_{t}$ - horizontal tensile strains at the bottom of the asphalt layer, $E_{1}-$ asphalt elasticity modulus.

\section{Effects of interface condition on life of pavement structure}

Cases A to D in the linear elastic analysis (Table 2) were used to compute the stresses, strains, and displacements in an aggregate base structure for a combination of 4 conditions for the asphalt granular base interface. The maximum and minimum strains from both radial and circumferential calculated strains are presented in Table 3. When the binder is fully bonded to the base but loses the bonding with the wearing course, the location of critical strain, where the cracks are more likely to initiate, is at the bottom of the wearing course. If the binder layer loses the bond with both the soil-cement base and wearing courses, the strain values at the corresponding positions in the two asphalt layers are close in magnitude. Thus, the failure may appear first in either of the two layers.

Table 3 indicates that the horizontal strains at the top and bottom of the wearing course are significantly affected by the condition of the wearing-binder courses interface. If this interface is fully bonded, the strain range is mostly in the compressive domain. For the other interface conditions, the strain range shifts to the tensile domain $[15,16]$.

Table 3. Horizontal and vertical strains in pavement structure for cases (Microstrain) $[15,16]$

\begin{tabular}{c|c|c|c|c}
\hline \multirow{2}{*}{ Position } & \multicolumn{4}{|c}{ CASE } \\
\cline { 2 - 5 } & A & B & C & D \\
\hline $\begin{array}{c}\text { Top subgrade } \\
\text { (vertical-max) }\end{array}$ & -354 & -410 & -410 & -394 \\
\hline $\begin{array}{c}\text { Bottom asphalt layer } \\
\text { (horizontal-max) }\end{array}$ & 164 & 293 & 277 & 249 \\
\hline Fatigue life & $3,0 \mathrm{E}+8$ & $1,1 \mathrm{E}+6$ & $1,2 \mathrm{E}+6$ & $2,3 \mathrm{E}+6$ \\
\hline Serviceability life & $3,9 \mathrm{E}+7$ & $2,2 \mathrm{E}+7$ & $2,4 \mathrm{E}+7$ & $2,6 \mathrm{E}+7$ \\
\hline
\end{tabular}

If the bonding between the binder and the base layers is also, the tensile strains are smaller than for the fullbond case. When the bonding between wearing and the binder layers only lost, the binder layer deforms with the base layer, so the strain range shifts toward the compressive domain. As for the wearing course, the highest tensile radial strains are significantly affected by the condition of the binder base interface. The interface without tack coat leads to slightly longer serviceability life than the interface with a tack coat regardless of the condi- 
tion of the binder-base interface and to almost double fatigue life if the binder-base interface is fully bonded.

The interface condition also affects the distribution of stresses and strains in the lower layers of the road structure. The maximum tensile strains at the bottom of the granular base well as the maximum vertical strain at the top of the subgrade increase when the full bond at the two interface is lost. Again, the loss of bonding between the binder and the base layer affects the magnitude of strains more than the loss of bond between the two asphalt layers. Consequently, it is expected that the condition of the two interface will influence the accuracy of layer moduli back calculation determination by the falling weight deflectometer techniques.

\section{Investigation of relationship between this model and experimental data}

We then applied our mathematical bonding model to the experimental data measured by experimental report. We requested and asked some question from Iranian road engineering and we received their viewpoints about the average reduction of a flexible pavement life and serviceability of road with weak interface condition. Table 4 shows different cases and average reduction of pavement life estimated by road engineers.

Table 4. Average reduction of pavement life that estimated by road engineers and this model

\begin{tabular}{c|c|c|c|c}
\hline \multirow{2}{*}{ Questions } & \multicolumn{4}{|c}{ CASE } \\
\cline { 2 - 5 } & $\mathrm{A}$ & $\mathrm{B}$ & $\mathrm{C}$ & $\mathrm{D}$ \\
\hline $\begin{array}{c}\text { Engineer's } \\
\text { estimation of reduction } \\
\text { of pavement life }\end{array}$ & $40 \%$ & $30 \%$ & $40 \%$ & $70 \%$ \\
\hline $\begin{array}{c}\text { Reduction of pavement } \\
\text { life estimated by this } \\
\text { computer model }\end{array}$ & $70 \%$ & $60 \%$ & $100 \%$ & $90 \%$ \\
\hline
\end{tabular}

\section{Conclusions}

The interface condition affects the distribution of stresses and strains in the lower layers of the road structure. The maximum tensile strains at the bottom of the granular base well as the maximum vertical strain at the top of the subgrade increase when the full bond at the two interfaces is lost. Again, the loss of bonding between the binder and the base layer affects the magnitude of strains more than the loss of bond between the two asphalt layers.

The behaviour of in-service pavements proves that the interface condition significantly affects the distribution of stresses and strains in flexible pavement structures and thus their performance. Therefore, the success of mechanistic design methods for pavement structures in which the computation of stresses and strains is a key component, depends on a reliable interface condition model. The existing mechanistic design methods consider full bond or complete slip between pavement layers or use friction-type approach to model the interface condition. Few models use the interface reaction modulus to model interface behaviour, but the modulus is considered independent of the normal stress level or temperature.

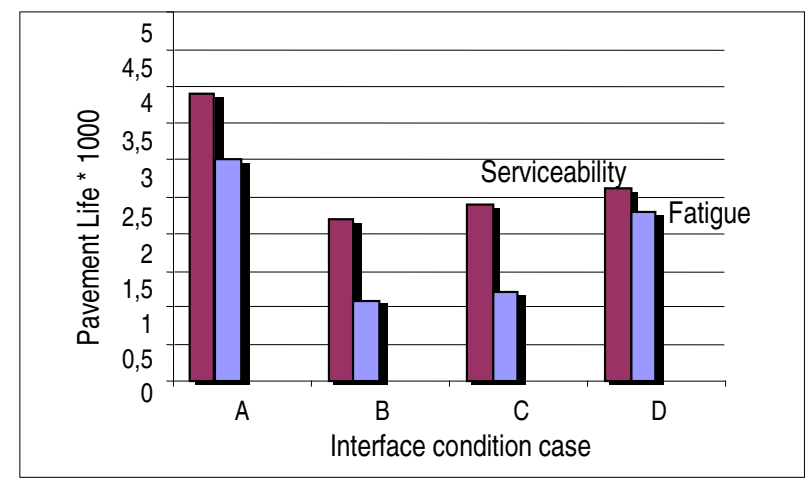

Fig 2. Fatigue and serviceability lifes for different cases of intrface condition

This study aimed to determine the effect of interface condition. Transfer functions for serviceability and cracking were used to estimate the lives of the two pavements. The study led to the following major finding $[15,16]$.

- For flexible pavements, the condition of the interface between the wearing and binder courses dramatically changes the strain field in the wearing and binder layers and may increase the vertical strains at the top of the granular base and subgrade layers by up to $20 \%$ (Fig 2).

- For most of the cases studied, the interface with tack coat leads to the development of slightly higher strains and deflections than the interface without a tack coat. Effects might be different if loads of different magnitudes are applied or at a different temperature. The relationship between the vertical stress and displacement changes with the normal stress and temperature. Also the effect of the environment could not be considered in this analysis.

\section{References}

1. ROMANOSCHI, S. A. Characterization of pavement layer interface. $\mathrm{PhD}$ dissertation. Louisiana State University, Baton Rouge, USA, 1999.

2. HAMMONS, M. I. Development of an analysis system for discontinuities in rigid pavements. $\mathrm{PhD}$ dissertation, Louisiana State University, Baton Rouge, 1996.

3. UDDIN, W.; PAN, Z.; NOPPAKUNWIJAI, P.; PLAXICO, C. A. and HACKETT, R. M. Finite-Element Dynamic Analysis of Distresses Asphalt Pavements. In Proc of $8^{\text {th }}$ International Conference on Structural Design of Asphalt Pavements. Seattle, USA, 1997, p. 732-739.

4. ZAGHLOUL, S. M.; ANDERTON, G. L. and SMITH, D. Use of a Three-Dimensional Dynamic Finite Element Model to Study the Effect of Unbound Layer Characteristics on Pavement Response to a Moving Aircraft Load. In Proc of $74^{\text {th }}$ Annual Meeting of the Transportation Research Board. Washington, DC, USA, Jan 1995, p. 341353.

5. JASON, K. Three-Dimensional Finite Element Modeling of Multi-Layered System. PhD. Dissertation, University of Illinois at Urbana-Champaign, USA, 1999.

6. Hot-Mix Asphalt Paving Handbook. AC 150/5370-14, U. S. Army Corps of Engineers, Washington, USA, 1991. 
7. Prime Coat Use. Technical Bulletin. OCAPE, The Ohio Center for Asphalt Pavement Education, Columbus, USA, 2002.

8. OGLESBY, C. H. and HICKS, R. G. Highway Engineering. 4th Ed, John Wiley \& Sons, New York, 1982.

9. Effect of Weather on Highway Construction. NCHRP, Synthesis of Highway Practice 47, Transportation Research Board, National Research Council, Washington, DC, 1978.

10. Asphalt Paving Manual. Manual Series No 8 (MS-8), Second Edition, The Asphalt Institute, Lexington, KY, 1965.

11. MANTILla, C. A. and BUTtON, J. W. Prime Coat Methods and Materials to Replace Cutback Asphalt. Research Report TTI 0-1334, Texas Transportation Institute, Texas A \& M University, 1994.

12. UZAN, J.; LIVNEH, M. and ESHED, Y. Investigation of Adhesion Properties Between Asphaltic Concrete Layers. In Proc of the Association of Asphalt Paving Technolo- gists, Vol 47, Lake Buena Vista, FL, Feb 1978, p. 495521.

13. METCALF, J. B.; Li, Y.; ROMANOSCHI, S. A. and RASOULIAN, M. Comparison of Louisiana's Conventional and Alternative Base Course under Accelerated Loading. Louisiana Transportation Research Center, Baton Rouge, 1999.

14. CLAESSEN, A. I. M.; EDWARDS, J. M.; SOMMER, P. and GE, P. Asphalt pavement Design: The Shell Method. In Proc of 4th International Conference on the Structural Design of Asphalt Pavements. Ann Arbort, Michigan, USA, 1977, p. 39-74.

15. ZIARI, H. and KHABIRI, M. M. Effects of Interface Condition on the Fatigue Life of Flexible Pavement. In Proc of Isfahan Conference. Iran, 2003, p. 361-367.

16. ZIARI, H. and KHABIRI, M. M. Effects of Interface Condition on the Rutting of Flexible Pavement. In Proc of Conference on Asphalt and Bitumen. Iran, 2004, p. 60-62.

\section{SUSIETIES BŪKLE்S IৃTAKA NESTANDŽIŲUU DANGŲ TARNAVIMO TRUKMEI NUMATYTI}

\section{H. Ziari, M. M. Khabiri}

\section{Santrauka}

Straipsnyje nustatyta susieties būklès įtaka nestandžiujų kelio dangų tarnavimo trukmei numatyti. Pagal taikytą metodiką anksčiau sukurtas sudètinis susieties modelis buvo įdiegtas į Kenlayer programą tam, kad būtų galima apskaičiuoti ịtempius ir deformacijas tipinèse nestandžiujų kelio dangų konstrukcijose. Dangos naudojimo trukmė apskaičiuota pasitelkiant sluoksnių perkèlimo funkcijas nuovargio plyšiams ir ribinio tinkamumo eksploatacijai. Esamų dangų elgsena rodo, kad dangos sluoksnių tarpusavio surišimo būklè yra labai svarbi kelio dangos konstrukcijos kokybei. Ankstyvas dangos ruožuc irimas dèl sluoksniu atsiskyrimo, dèl kurio dangos konstrukcijos itempiai ir deformacijos persiskirsto, yra gana dažnas, ypač tose vietose, kur transporto priemonės sukelia horizontaliąsias jègas. Apskaičiuojant kritinius įtempius ir deformacijas, daugumai mechaninio nestandžiujų dangų konstrukcijų projektavimo metodikų imama, kad dangos sluoksniai yra visiškai surišti arba visiškai nesurišti.

Reikšminiai žodžiai: būklè, tiesinis tamprumo modelis, pagruntavimas, nestandžioji danga, Kenlayer programa, sluoksnių perkèlimo funkcijos, nuovargis, vėžių susidarymas.

Hassan ZIARI. Professor of engineering in the College of Civil Engineering at the Science and Technology University of Iran. Member of Iranian pavement association. Member of Editorial board of Traffic Journal in Iran. Member of Traffic Committee of Civil Engineering association. His research interests include the behaviour of hot asphalt pavement, pavement mix design, concrete mix design, road engineering.

Mohammad Mahdi KHABIRI. PhD student of engineering in the Civil Engineering at the Science and Technology University of Iran and Lecturer of civil engineering in Vali-Asr Rafsanjan University. Member of Iranian pavement association and member of traffic Committee of Civil Engineering association in Yazd. His research interests include the pavement preservation maintenance, hot mix asphalt, and pavement analytical design. 